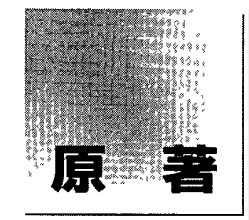

2003年 4 月 9 論文受付

論文受理

2003年7月15日

Code No. 251

\section{マイクロディスク法による \\ Multi-slice Spiral CTの体軸方向のMTF測定 \\ ービーズ法との比較と幾何学的な影響に関する検討一}

\author{
原 孝則 1 , 3) - 津坂昌利 2$) \cdot$ 桜井直之 ${ }^{3)}$ \\ 1) 名古屋大学大学院医学系研究科医療技術学専攻 \\ 2)名古屋大学医学部保健学科 \\ 3)総合病院中津川市民病院診療部放射線技術科
}

\section{緒 言}

デルタ関数の入力によるcomputed tomography (以 下, CT)のsection sensitive profiles (以下, SSP)の測 定方法および評価は，これまで国内外において多数報 告されている1 6). single-slice spiral/helical CT (以下， SSCT)の普及に伴い，本邦では1997年に花井ら》によ

\begin{abstract}
って一般医療施設における沉用性の高い簡便な測定方 法としてビーズ法が推奨された. multi-slice spiral/helical CT(以下，MSCT) ${ }^{8 \sim 10)}$ が普及した近年も，これま でと同様に，ビーズ法を用いてスライス厚や体軸方向 の空間分解能の評価が行われている.

modulation transfer function $(\mathrm{MTF})$ によってCTの体
\end{abstract}

\title{
Measurement of Modulation Transfer Function in Z-axis for Multi-slice Spiral CT Using the Micro-disk Method: Comparison with the Bead Method and Examination of Geometric Influence
}

\author{
TAKANORI HARA, ${ }^{1,3)}$ MASATOSHI TSUZAKA, ${ }^{2)}$ and NAOYUKI SAKURAI ${ }^{3)}$ \\ 1) Master Course in Radiological and Medical Laboratory Sciences, Nagoya University Graduate \\ School of Medicine \\ 2) School of Health Sciences, Nagoya University \\ 3)Department of Radiology, Nakatsugawa Municipal General Hospital
}

Received April 9, 2003; Revision accepted July 15, 2003; Code No. 251

\section{Stmanary:}

Many methods of measuring the section-sensitive profile (SSP) of computed tomography (CT) by the input of a delta function have been reported. In Japan, the bead method is used as a common measurement because of the high flexibility of the multi-purpose method. However, the intensity of the response of the bead method tends to decline, creating a relatively large error in the base of section-sensitive profiles. A problem is considered to be the accuracy of measurement in evaluating spatial resolution along the z-axis in multi-slice spiral/helical CT (MSCT). We therefore evaluated the modulation transfer function (MTF) by conducting research with the micro-disk method $(100 \mu \mathrm{m}$ thickness and $1.0 \mathrm{~mm} \phi$ diameter $)$ and the bead method $(1.0 \mathrm{~mm} \phi$ diameter $)$ for the same input width. Moreover, in the micro-disk method, we also examined alignment, circular region of interest (ROI), and the energy characteristic. Our comparison of MTFs obtained by the micro-disk method and the bead method showed that the former resulted in a higher value and lower standard deviation. The difference was significant at $\mathrm{p}<0.01$. Measurement using the micro-disk method did not show significant differences in terms of alignment and ROIs. Moreover, the energy characteristic was not indicated. This research demonstrated that the accuracy of MTF measurement with the micro-disk method was greater than that with the bead method, and it was found that there was no influence on the actual measurement level of the geometric structure with the micro-disk method.

\section{Wow words: Modulation transfer function (MTF), Multi-slice spiral computed tomography (MSCT), Computed tomography, Micro-disk method, Section sensitivity profile (SSP)}


軸方向の空間分解能を評価する方法は，体軸方向に対 して単位インパルス(デル夕関数)の入力を有するファ ントムを撮像し，SSPをフーリエ変換して求めるのが 一般的である。しかしMSCTではSSPの裾野およびべ 一ス部分のCT值が，これまでSSCTではあまり問題と ならなかった誤差要素によって, SSPの形状自体に影 響する11 13). これには, 検出器の多列化に伴うdetector pitchのサンプリングロケーションにおける感度差 (検出器自身の感度差とも関係する), ファントムを支 持するアクリル(円柱)物質等の内部不均一性, そして 新しいフィルタリング再構成補間法などが原因として 考えられる．したがって，MSCTの体軸方向分解能を MTFとして正確に評価するには，(1)得られたSSPの裾 野に対してアクリル等の支持物質の変動誤差等を何ら かの方法で考慮したうえで指数関数により外挿処理す るか，または(2)デル夕入力の信号強度を裾野の值の変 化に対して十分高く保ち，変動誤差を無視可能なレべ ルにして外挿処理することが必要である.

そこで本論文ではビーズ法とコイン法においてコイ ン構造を小さく改良した(2)に相当する手法として新し いファントム法(以下，マイクロディスク法）を用い て, 各条件下における測定精度をMTFにて評価し, マ イクロデイスク法の一般医療施設における体軸方向の MTF測定手法としての現実的な有効性を検討したので 報告する。

\section{1. 使用機器と撮像条件}

- MSCT装置 : SOMATOM Plus4 Volume Zoom 4 列 (SIEMENS社製)

・体軸方向空間分解能ファントム：

1)マイクロディスクファントム(旭日計測社製) ディスク部： $\phi 1.0 \mathrm{~mm}, 100 \mu \mathrm{m}$ 厚, 材質 $: \mathrm{Pt}$

2)ビーズファントム(旭日計測社製)

ビーズ部： $\phi 100 \mu \mathrm{m}$, 材質 $: \mathrm{Pb}$

体軸方向空間分解能ファントムであるマイクロディ スク法とビーズ法の仕様，および支持装置に取り付け た概観をFig. 1に示す.

体軸方向空間分解能ファントムは撮像領域内におけ る位置依存性 ${ }^{14)}$ 避けるためFOV中央に配置した。ビ ーズ法では『ラセンCTの物理的な画像特性の評価と測 定法に関する報告』》に準拠し，マイクロディスク法は ディスク面をXY平面に対して平行 $(0$ 度)となるように アライメントを正確に調整した。

撮像条件は方法2-1-1，2-1-2，2-1-3に扮いて $120 \mathrm{kV}, 100 \mathrm{Eff} . \mathrm{mAs}$, rot.time $1.0 \mathrm{sec} / \mathrm{rot}$, slice collimation $4 \times 1.0 \mathrm{~mm}$ として測定した．画像の再構成は腹部 標準関数 $($ B30f $)$, FOV $50 \mathrm{~mm}(1$ pixel $=0.098 \mathrm{~mm} \doteqdot$ $0.1 \mathrm{~mm})$ ，再構成スライス厚，再構成間隔はそれぞれ

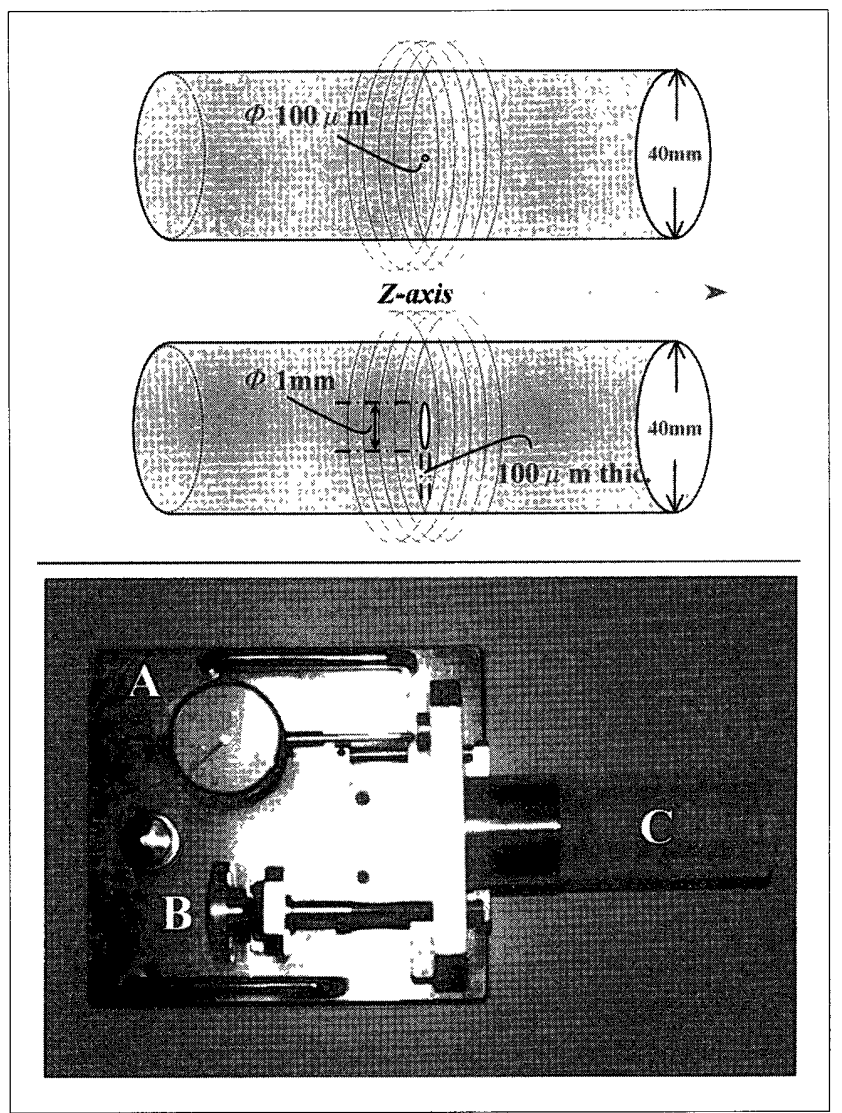

Fig. 1 Schema of the phantom (micro-disk method and bead method) used for research and phantom support equipment.

A: Minute drive dial, B: distance gauge, C: phantom main part.

$1.0 \mathrm{~mm}, 0.1 \mathrm{~mm}$ である。

\section{2. 方 法}

\section{2-1 MTFの評価}

2-1-1 体軸方向分解能ファントムのPitchによる影響 測定領域としてマイクロディスク法ではregion of interest (ROI) を約 25 pixels $\left(0.5 \times 0.5 \mathrm{~mm}^{2}\right)$, ビーズ法の ROIは外接しない限界7)の約 1000 pixels $\left(3.1 \times 3.1 \mathrm{~mm}^{2}\right)$ と した. detector pitch (以下, Pitch)3.0，6.0についてそ れぞれ 5 回測定し，体軸方向分解能ファントムのPitch による影響を評価した。

\section{2-1-2マイクロディスク法のアライメントによる影 響}

マイクロディスクファントムのアライメントをXY 平面に対して 0 度と 2.5 度傾けた場合のトポグラム側 面像をFig. 2に示す。これよりディスク面が 0 度と 2.5 度傾いた場合のアライメントによる影響を調べた。 ROIは約 25 pixels $\left(0.5 \times 0.5 \mathrm{~mm}^{2}\right)$ として, Pitch 3.0, 6.0 についてそれぞれ 5 回測定して評価した。 

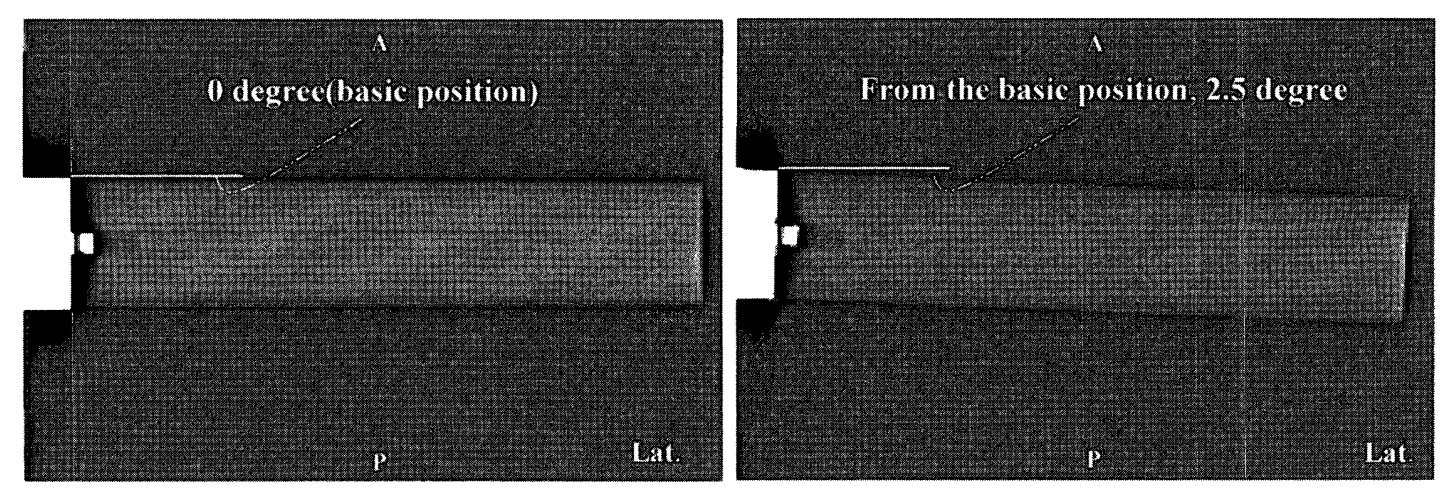

Fig. 2 Side image of the topogram (survey radiograph)at 0 degree and 2.5 degrees to the $X-Y$ plane in alignment of a micro-disk phantom.

\section{2-1-3 アライメント不良時のROIの大きさによる影 響}

マイクロディスク法を含むコイン法は, アライメン ト不良時の傾斜角度と, 設定するROIの直径 (大きさ) との関係により, 計算上実効的な入力幅が広くなる. これを確認するために，XY平面に対してアライメン 卜を2.5度傾け，設定するROIの大きさをディスク中央 より基準の約 25 pixels $\left(0.5 \times 0.5 \mathrm{~mm}^{2}\right)$ と，像に内接する 限界の約 400pixels $\left(2.0 \times 2.0 \mathrm{~mm}^{2}\right)$ に変化させてアライ メント不良時のROIの大きさによる影響を調べた。こ れをPitch 3.0，6.0についてそれぞれ 5 回測定して評 価した。

\section{2-2 測定管電圧による影響}

マイクロディスクファントムを撮像領域内の中央に 寝台の移動と独立させ配置した。ファントム支持装置 に取り付けられたダイアル(Fig. 1，写真のB）を手動で 操作し，マイクロディスクファントムをcollimation幅 の $1 / 10(0.1 \mathrm{~mm})$ に微小移動させてデー夕を取得した。

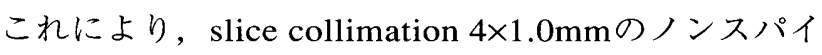
ラルスキャンにおけるSSPの形状を, 本CT装置にて得

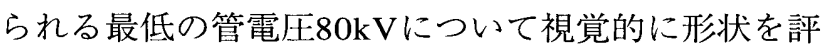
価した．他の撮像条件は100Eff.mAs, rot.time 1.0sec/ rot, 100Eff.mAs, 腹部標準関数 (B30f) である.

なお, Eff.mAs ${ }^{15)}$ は下式により定義される。

Eff.mAs $=4 \cdot \mathrm{mA} \cdot$ rot.time $/$ Pitch

$(\mathrm{mA}$ : 管電流, rot.time：回転時間, Pitch : detector pitch)

\section{3. 体軸方向空間分解能ファントムのROIの設定方法 とMTF解析}

3-1 ROIの設定方法(Fig. 3)

(1)各撮像条件で得たSSPのプロファイルピークを示す CT画像をあらかじめ求め, そのXY平面に扮ける像
(応答)の中心を通過するプロファイル(1ライン)を得 た. (2)次にビーズ法はプロファイル（1 ライン)より， そのベースレベルの幅にわずかに接しないROI(本研 究では約1000pixels), マイクロディスク法はプロファ イルより，そのピークCT值に対して約 $95 \%$ CT値とな るROI(本研究では約25pixels)を決定した. (3)ビーズ 像, マイクロディスク像を中心にROIを再設定し MSCT装置上でCT值を実測してSSPを得た(Fig. 4).

\section{3-2 MTF解析}

CRT上のROIより得られる連続したCT值を正規化 してSSPを得る。上記の条件下において得られたSSP をフーリエ変換によりMTFを計算して統計的に処理を した.

\section{4. 結 果}

\section{4-1 体軸方向分解能ファントムのPitchによる影響}

デルタ入力として, 入力信号が同じ $100 \mu \mathrm{m}$ の両手法 (マイクロディスク法, ビーズ法)に扔いて, ビーズ法 に比べてマイクロディスク法によるMTFは中空間周波 数領域にて高い値を示し, 標準偏差も小さかった.

Fig. 5においてマイクロディスク法でのMTFはPitchに よる差を認めなかった。一方, ビーズ法ではPitch 6.0 の方がPitch 3.0 より特に中空間周波数領域において低 値となり，その標準偏差も大きかった。ママイクロディ スク法とビーズ法より得られたMTFは $1 \%$ 水準で有意 差が認められた(Table).

\section{4-2マイクロディスク法のアライメントによる影響}

Fig. 2に示すよjにマイクロディスク法にてディス ク面をXY平面に対して 0 度と2.5度傾けた場合のMTF は重なり，変化はみられなかった。これはPitchが 3.0，6.0に扔いても同様であった. Fig. 6に抢いてMTF は $1 \%$ 水準でファントムアライメントによる影響は認 められなかった. 

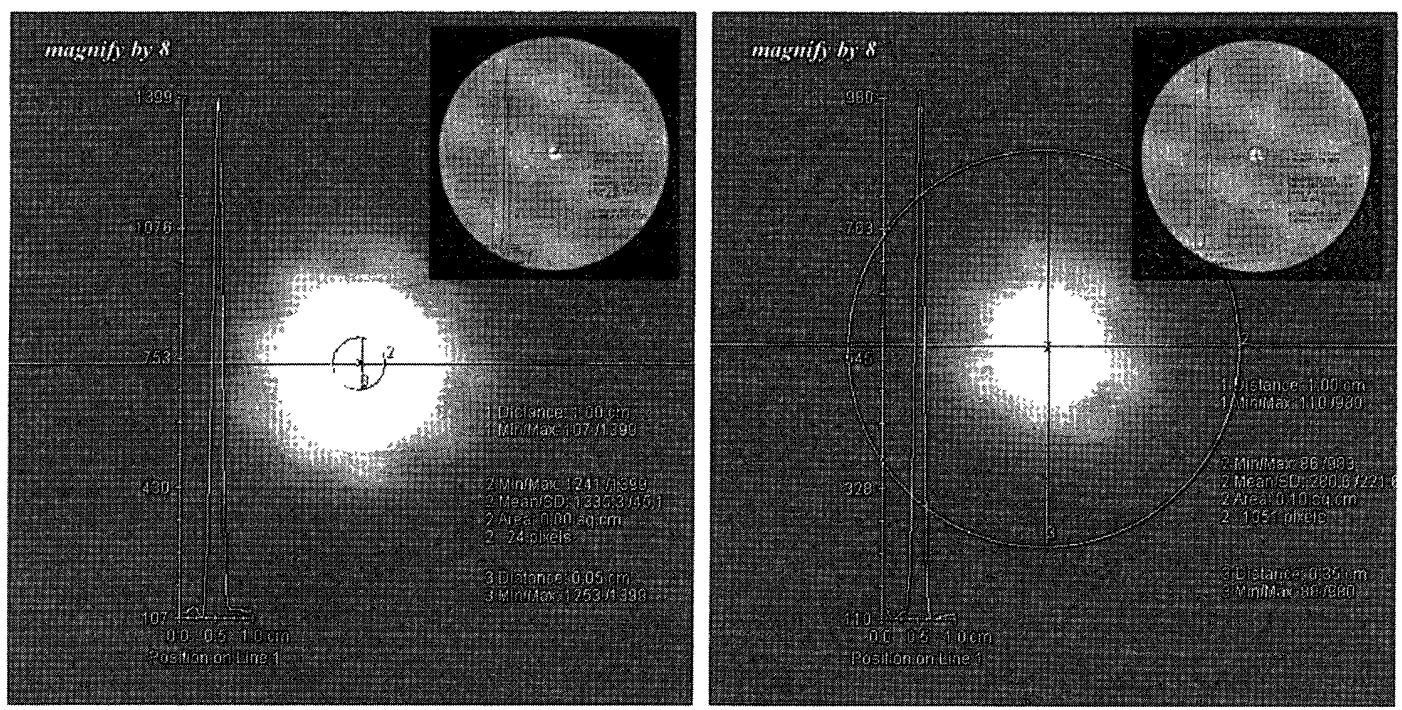

Fig. 3 Setup of circular region of interest (ROI) in the micro-disk method (a) and bead method (b). Theoretically, with the bead method, setup of the ROI must surround the image of a bead. However, with the micro-disk method, since the setup of the ROI is possible inside, the CT-value of the response is higher than in the bead method.
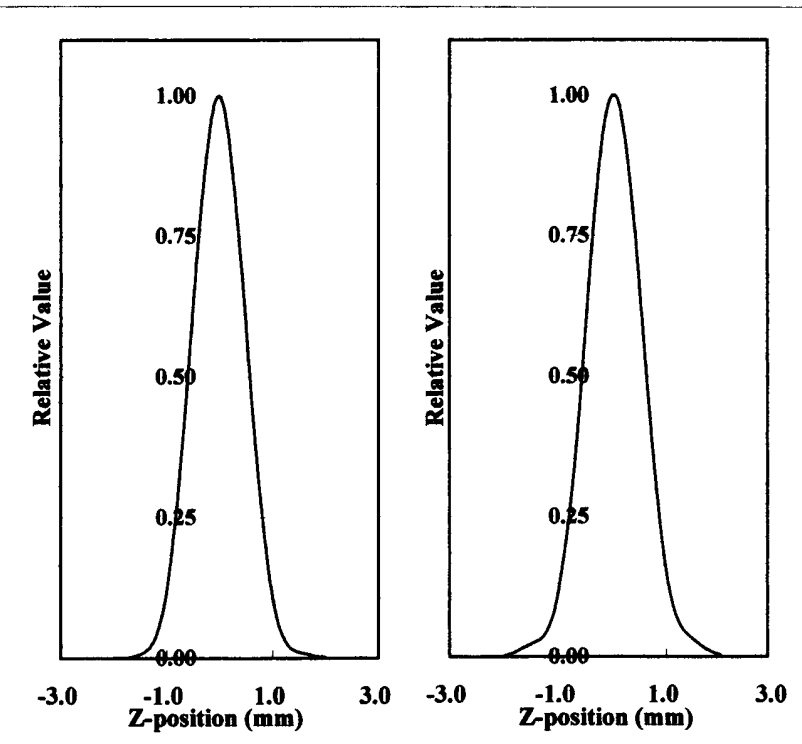

a

b

Fig. 4 Section sensitivity profiles. Example of detector pitch 3.0. The micro-disk method and bead method were used for measurement.

(a) Micro-disk method.

(b) Bead method.
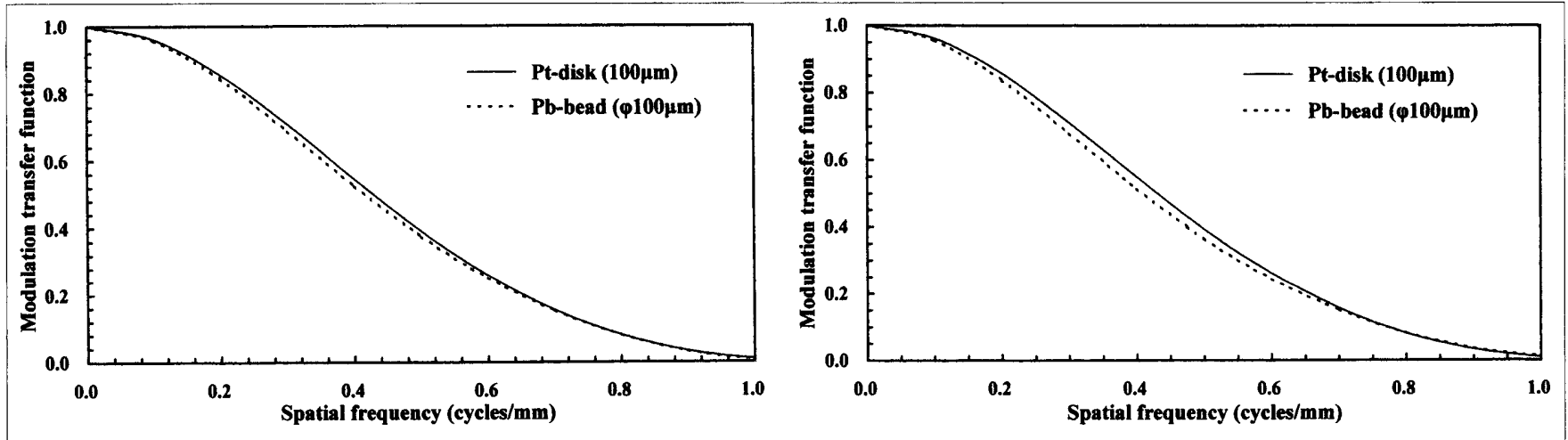

Fig. 5 Modulation transfer function (MTF) obtained by the bead method and micro-disk method. Solid line shows the micro-disk method, and dashed line shows the bead method. MTF was obtained from the Fourier transform of section sensitivity profiles and shows a significant difference in two kinds of method.

(a) Detector pitch 3.0.

(b) Detector pitch 6.0. 
Table Comparison of modulation transfer functions acquired by the bead method and micro-disk method with the same input width of $100 \mu \mathrm{m}$.

\begin{tabular}{cccc}
\hline \hline Detector Pitch & (cycles $/ \mathrm{mm})$ & Bead $(\mathrm{Pb})$ & Odeg.Disk 25pixels $(\mathrm{Pt})$ \\
\hline 0.1 & $0.958 \pm 0.001$ & $0.961 \pm 0.001$ \\
0.2 & $0.844 \pm 0.006$ & $0.855 \pm 0.006$ \\
0.3 & $0.688 \pm 0.011$ & $0.709 \pm 0.007$ \\
$* 3.0$ & 0.4 & $0.524 \pm 0.014$ & $0.545 \pm 0.007$ \\
& 0.5 & $0.375 \pm 0.015$ & $0.391 \pm 0.007$ \\
& 0.6 & $0.252 \pm 0.012$ & $0.260 \pm 0.004$ \\
& 0.7 & $0.154 \pm 0.007$ & $0.157 \pm 0.002$ \\
& 0.8 & $0.082 \pm 0.002$ & $0.082 \pm 0.002$ \\
& 0.9 & $0.033 \pm 0.003$ & $0.034 \pm 0.001$ \\
& 1.0 & $0.008 \pm 0.002$ & $0.010 \pm 0.002$ \\
\hline 0.1 & $0.956 \pm 0.003$ & $0.962 \pm 0.002$ \\
& 0.2 & $0.838 \pm 0.010$ & $0.858 \pm 0.009$ \\
& 0.3 & $0.678 \pm 0.015$ & $0.711 \pm 0.009$ \\
& 0.4 & $0.513 \pm 0.018$ & $0.549 \pm 0.011$ \\
& 0.5 & $0.364 \pm 0.017$ & $0.392 \pm 0.010$ \\
& 0.6 & $0.245 \pm 0.018$ & $0.262 \pm 0.011$ \\
& 0.7 & $0.151 \pm 0.015$ & $0.156 \pm 0.008$ \\
& 0.8 & $0.082 \pm 0.009$ & $0.081 \pm 0.006$ \\
& 0.9 & $0.036 \pm 0.006$ & $0.034 \pm 0.003$ \\
& 1.0 & $0.013 \pm 0.003$ & $0.010 \pm 0.001$ \\
\hline
\end{tabular}

${ }^{*} \mathrm{p}=0.00568 *{ }^{*} \mathrm{p}=0.00876$
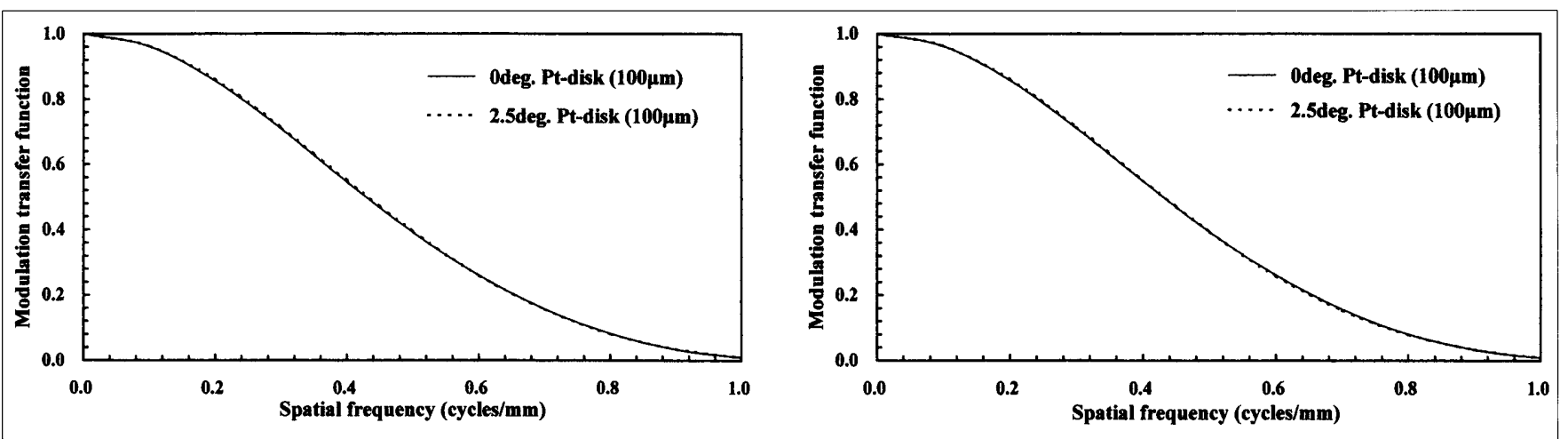

Fig. 6 Modulation transfer function (MTF) of a case in which the micro disk was inclined. Solid line shows 2.5 degrees, and dashed line shows 0 degrees. MTF measured at a different angle is mostly overlapping.

(a) Detector pitch 3.0.

(b) Detector pitch 6.0.

4-3 アライメント不良時のROIの大きさによる影響 マイクロディスク法にてディスク面をXY平面に対 して2.5度傾け，かつ，設定するROIの大きさを約 25pixels と約400pixels と設けた場合のMTFは重なり， これはPitchが3.0，6.0においても同様であった。Fig. $7 に お い て \mathrm{MTF}$ 1\% 水準でROIの大きさによる影響 は認められなかった。

\section{4-4 測定管電圧による影響}

Fig. 8のrow 1 から row4は各検出器のSSPを示す. row 1, row4の外側は中央のrow2, row3と比較して検 出器前面のコリメータの制御でマイクロディスクから の半影が抑えられ，急峻な応答となっている12). また collimationごとに観察されるSSPは管電圧が最低の $80 \mathrm{kV}$ においても，顕著な変形》热めなかった。

\section{5. 考 察}

デルタ関数によるspiral/helical CTの体軸方向の空間 分解能測定理論は, 入力信号である単位インパルスが 持つ一様の信号情報成分が，撮像条件によってSSPと 

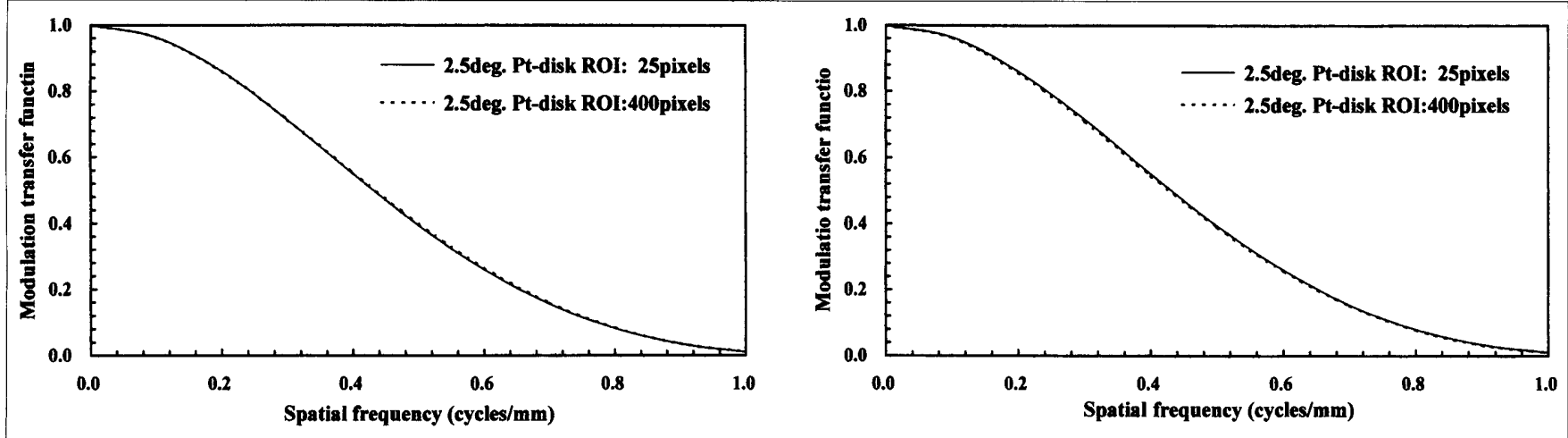

Fig. 7 Modulation transfer function (MTF) according to difference in size of circular region of interest (ROI) (micro disk is tilted 2.5 degrees). Solid line shows ROI of about 25pixels, and dashed line shows ROI of about 400 pixels. MTF measured at a different $\mathrm{ROI}$ is mostly overlapping.

(a) Detector pitch 3.0.

(b) Detector pitch 6.0.

して変化した場合に，その信号情報成分がどの程度減 衰したかを測定することで評価される。したがって理 論的には入力信号の強度はMTFに影響しない。しかし 実験系では入力信号である単位インパルスのベース部 分にモダリティ固有のノイズ等が誤差として存在する ので，測定の理論的な忠実性を高めるうえでS/N (signal to noise) 比を高めることが重要である.

本研究で比較した両手法に扔けるファントムの入力 幅は公称值 $100 \mu \mathrm{m}$ と同じである。しかしビーズにて得 られる実測のCT值はマイクロディスク $(\phi 1.0 \mathrm{~mm}$,

ROI：約 25 pixels)の1/5程度と低いため, 正規化後の SSPはマイクロディスク法と比較するとアクリル円柱 内のベース変動が相対的に強く現れる。この変動によ る誤差によって，出力信号であるSSPのボケ具合を示 す裾野のわずかな応答変化が変動誤差のなかに埋もれ てしまうため，SSPをフーリエ変換して得られるMTF は中空間周波数領域に低下を認める。更に，Pitchのサ ンプリングロケーションにおける感度差(検出器自身 の感度差とも関係する)により，Pitch 3.0 とPitch 6.0で も若干異なるMTFの測定值となったと考える。この点 に関してマイクロディスク法は，入力信号のS $/ \mathrm{N}$ 比が ビーズ法よりも遥かに高い (ROI：25pixelsにて約 $1250 \mathrm{HU})$ ため理論的な忠実性がビーズ法より良くな り，裙野は実際のボケ具合をビーズ法よりも忠実に表 現可能である。したがって，外抻する過程でその誤差 を無視可能なレベルとして扱いやすく，MTFは精度 ・ 再現性とも良好な測定值となったと考えられた。

マイクロディスク法 $(\phi 1.0 \mathrm{~mm})$ による評価法を一般 医療施設における現実的な手法とし取り入れるには実 験系において(1)理論的 (構造的)問題，(2)測定時の問題 点をおおむねクリアする必要がある。

(1)『理論的 (構造的)問題点』は現行のコイン法 $(\phi 10$ $40 \mathrm{~mm}$ ) と同様にファンビームのX線束による焦点から 見た形状に対する影響(変化)と線質(実効エネルギー)

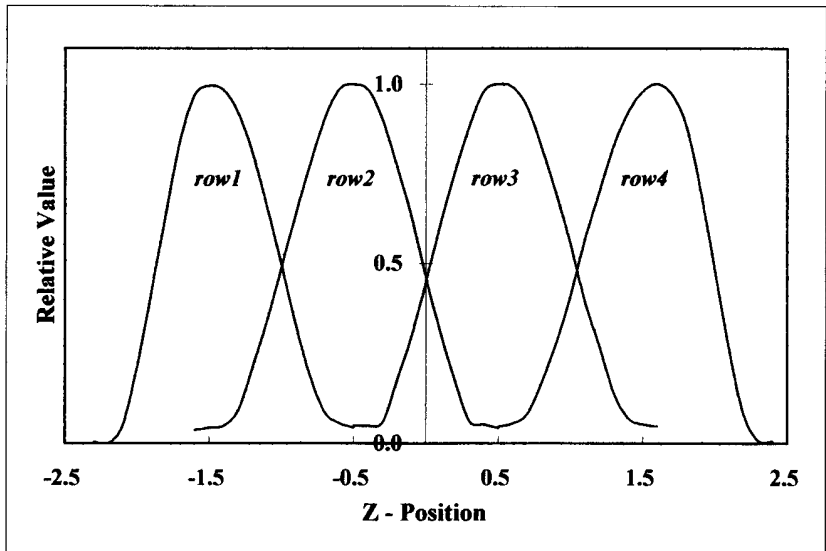

Fig. 8 Section sensitivity profiles on z-axis for non-spiral computed tomography scanning using the micro-disk method (slice collimation $4 \times 1.0 \mathrm{~mm}$ ). The micro disk feed distance per $360^{\circ}$ revolution of the gantry is $100 \mu \mathrm{m}$.

の影響である。

形状の変化に関しては，今日の一般的なCT装置の 名目の焦点サイズが $0.5 \sim 2.0 \mathrm{~mm}$ 程度 ${ }^{16)}$ との報告よ り，今回のコイン構造を小さく改良した新しいマイク ロディスクは $\phi 1.0 \mathrm{~mm}$ であり，焦点に対する見かけの 形状変化を考慮した大きさと考える。また線質は名目 の出力管電圧が同じでも，X線管の前面にあるフィル 夕厚(材質)により実効エネルギーが変化するため厳密 には半価層等により，その影響を検討する必要があ る. しかしFig. 8に示すように管電圧80kVの実験結果 で，ノンスパイラル(ヘリカル)のSSPの頂点付近に顕

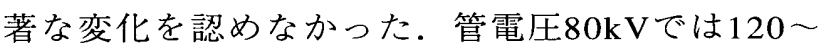
$140 \mathrm{kV}$ に比べて光電吸収の割合が大きく, 線減弱係数 が大きい。これょり，他のCT機種を含め，一般的に 臨床で使用する管電圧 $120 \mathrm{kV} ， 135 \mathrm{kV} ， 140 \mathrm{kV}$ ではコ ンプトン散乱の割合が増えることから，上記の影響は 更に少なく問題ないと考える。 
(2)『測定時の問題点』は焦点から見た形状と関連して 測定時マイクロディスクのアライメント(傾き)の影響 である．本研究では，視覚的に十分に認識できる傾き として，2.5度傾斜させてMTFを評価した。これはア ライメント調整に際して肉眼で傾斜していると確認で き, 実際は起こりえないと思われる角度であるが, MTF測定結果には有意差は認められなかった。これは 結果4-3に示すようにROIの大きさを変えても同様で あった．計算上， $\phi 1.0 \mathrm{~mm}, 100 \mu \mathrm{m}$ 厚のデイスクを 2.5 度傾けた場合, ROIを約 25 pixels $\left(0.5 \times 0.5 \mathrm{~mm}^{2}\right)$, 400pixels $\left(2.0 \times 2.0 \mathrm{~mm}^{2}\right)$ に設定すると，焦点から見た 直下のディスクの入力幅は $120 \mu \mathrm{m}, 190 \mu \mathrm{m}$ 程度とな る.デルタ関数のMTFは 1.0 とされるが，これは理論 值であり，実験系ではファントムが入力信号となるの で，その入力信号幅(矩形波)上り得られるMTFに影響 され測定值を得ている.

ここで, 入力信号となる矩形波自体のMTFの影響を 比較するために, CT装置にて設定可能な最小の再構 成間隔を $100 \mu \mathrm{m}$ (一定)を基準とし, シミュレーション にて1.0cycles/mmまでのMTFを求め, 各周波数におけ る值の積分計算より，理論值からの情報の低下割合 (誤差)を比較した(Fig. 9)。この時, 理論值に対する 実験系のMTFに扔いて, 入力矩形波の幅が $100 \mu \mathrm{m}$ (評 価スライス厚の $1 / 10$ )では $5 \%$ 程度, $200 \mu \mathrm{m}$ (評価スラ イス厚の $1 / 5$ )では $6.5 \%$ 程度, $300 \mu \mathrm{m}$ (評価スライス厚 の1/3.3)では $9 \%$ 程度の情報の低下割合が誤差として あることが分かる。また，実際はCT装置において設 定不可能である $50 \mu \mathrm{m}$ を再構成間隔とすると, 入力矩 形波 $100 \mu \mathrm{m}$ に扔ける誤差は $3 \%$ 程度と低減される。

ここで重要なのは入力矩形波の幅が $100 \mu \mathrm{m}$ から $200 \mu \mathrm{m}$ に厚くなることによる情報量の差 (誤差) は 1.5 \%程度とわずかであることである。これは周波数空間 に伝達される情報量が被写体(入力矩形波)に対する再 構成間隔に依存 ${ }^{17}$, 18) するためである。したがって，入 力矩形波の幅 $100 \mu \mathrm{m}$ に対して再構成間隔が一定の $100 \mu \mathrm{m}$ では矩形波の持つ情報量をMTFに十分に反映 できないことでこのような結果となる。つまり, CT 装置は設定可能な最小の再構成間隔が100 $\mu \mathrm{m}$ なので, アライメント不良等により入力幅か $200 \mu \mathrm{m}$ と 2 倍程度 となっても, 傾かない場合と比較して誤差は計算上わ ずかで，なおかつ実効焦点サイズと焦点に対する見か けの形状があまり変化しないことも関係して, MTFに 有意差が認められなかったと考えられた.

これより25pixels $\left(0.5 \times 0.5 \mathrm{~mm}^{2}\right)$ 程度のROIを基準と した場合, $190 \mu \mathrm{m}$ 程度 (400pixelsのROIにてディスク

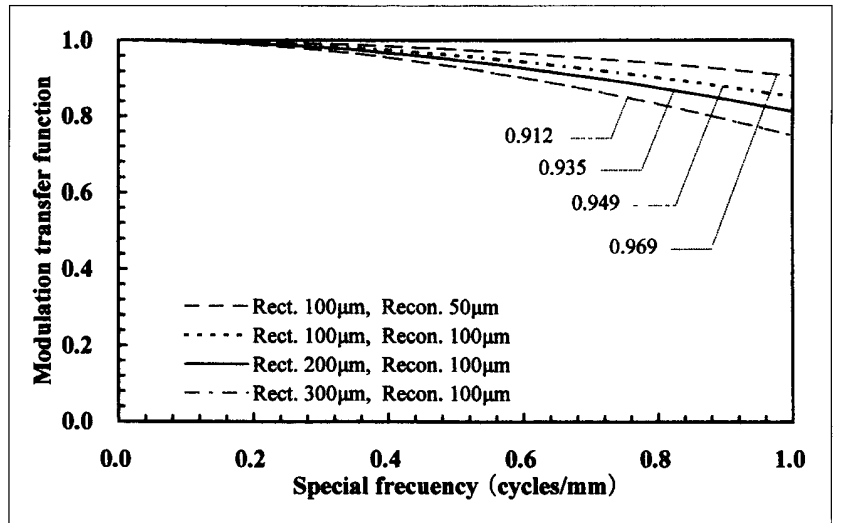

Fig. 9 Comparison of modulation transfer function (MTF) of an input rectangular wave by simulation. MTF depends on the width of the input rectangular wave and reconstruction increment in computed tomography.

を 2.5 度傾けて得られる実効的な入力幅と同程度)を仮 定すると，ディスクの傾きは単純計算より約10度とな るが,この実験系におけるMTF測定は何ら問題がない ことになる.しかし，影響が少ないとはいえ，測定の

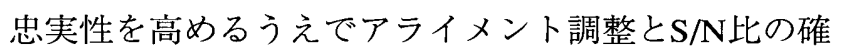
保は基本的な測定手順として重要であり, 注意深く行 うことはいうまでもない.

また，設定するROIをより小さくすることでS/N比 は良好となるがSSPを中心の 1pixelsで測定することは 問題であると考える。これはX線管と検出器が回転す るCT装置のスキャン特性より, XY平面において回転 中心の精度が不明確であることによる。

\section{6. 結 語}

マイクロディスク法による測定はデルタ入力の信号 強度が遥かに大きいためS/N比を高く保持できる。し たがって，MTF評価(測定)に扔いて誤差要因となる SSPのベース部分の変動による影響を無視できる程度 に抑えることが可能となる。また，マイクロディスク の幾何学的構造による測定時のアライメントの影響は 実測において無視できるレべルであった。

以上より，マイクロデイスク法は測定の手技が容易 で再現性も良く, 一般医療施設に扔いてMTFを精度良 く評価する簡便な測定方法である.

\section{謝 辞}

本実験を行うにあたりファントムを措りし，ご教 示いただいた名古屋市立大学病院中央放射線部市川勝 弘先生に深く感謝いたします。 


\section{参考文献}

1) Polacin A, Kalender WA, and Marchal G: Evaluation of section sensitivity profiles and image noise in spiral CT, Radiology, 185, 29-35, (1992).

2) Polacin A, Kalender WA, and Brink J, et al.: Measurement of slice sensitivity profiles in spiral CT. Med Phys, 21 (1), 133-140, (1994).

3) Kalender WA, Polacin A, and Suss C: A comparison of conventional and spiral CT: An experimental study on the detection of spherical lesions. J Comput Assist Tomogr, 18 (2), 167-176, (1994).

4）白石順二, 津田和良：CTにおけるスライス厚の測定：partial volume effectを用いた測定法. 日放技学誌，46(1)，2934, (1990).

5) 辻岡勝美 : ヘリカルCTシステムの技術的問題点: 性能評価 と実際の運用. 日放技学誌, 52(3)，389-396，(1996).

6）馬場 仁, 広渡 諭, 西村弘幸, 他: X線CTにおけるスラ イス感度分布の測定 : エアーギャップを用いた方法. 日放 技学誌, 53(4), 437-442, (1997).

7) 花井耕造, 石田智広, 井田義宏, 他：ラセンCTの物理的な 画像特性の評価と測定法に関する報告. 日放技学誌, 53 (11), 1714-1732, (1997).

8) Schaller S, Flohr T, Klingenbeck K, et al.: Spiral Interpolation Algorithm for Multislice Spiral CT-Part I: Theory. IEEE Trans Med Imag, 19(9), 822-834,(2000).

9) Hu H: Multi-slice helical CT: Scan and reconstruction. Med Phys, 26 (1), 5-18, (1999).

10) Taguchi $\mathrm{K}$, and Aradate $\mathrm{H}$ : Algorithm for image reconstruc- tion in multi-slice helical CT. Med Phys, 25 (4), 550-561, (1998).

11) Wang G, and Vannier MW: The effect of pitch in multislice spiral/helical CT. Med Phys, 26 (12), 2648-2653,(1999).

12) 原 孝則, 加藤秀記, 青木 力, 他: 不均等型検出器を有 するmulti-slice CTのSSPz と画像ノイズの基礎的検討. 日放 技学誌, 56(12), 1454-1460, (2000).

13) Fuchs T, Krause J, Schaller S, et al.: Spiral Interpolation Algorithms for Multislice Spiral CT-Part II: Measurement and Evaluation of Slice Sensitivity Profiles and Noise at a Clinical Multislice System. IEEE Trans Med Imag, 19(9), 835$847,(2000)$.

14）勝田昭一, 花井耕造, 国井岳夫, 他: ヘリカルCTにおける スライス感度プロフィールの撮像領域内位置依存性. 日放 技学誌，55(11)，1109-1114，(1999).

15) 村田勝俊：シーメンスのマルチスライスCT SOMATOM Volume Zoom. 日放技学誌, 56(12)，1406-1410， (2000).

16) Kalender WA: Computed Tomography. Publicis MCD Verlag, Germany, (2000).

17) Wang G, Vannier MW: Longitudinal resolution in volumetric x-ray computerized tomography-analytical comparison between conventional and helical computerized tomography. Med Phys, 21 (3), 429-433,(1994).

18)市川勝弘：空間分解能 現象と物理特性の密接な関係. INNERVISON, 13(12), 20-23, (1998).

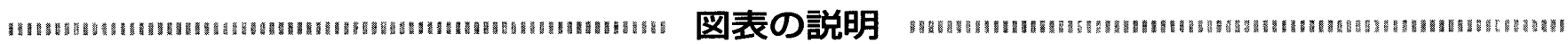

Fig. 1 研究に用いたファントム(マイクロディスク法とビーズ法)の模式図とファントム支持装置

$\mathrm{A} ：$ 微小駆動ダイアル, $\mathrm{B} ：$ 距離ゲージ, $\mathrm{C} ：$ ファントム本体

Fig. 2 マイクロディスクファントムのアライメントをXY平面に対して 0 度(平行) と 2.5 度傾けた場合のトポグラムの側面像

Fig. 3 マイクロディスク法(a)とビーズ法(b)に扔けるROIの設定方法

理論的にビーズ法ではROIの設定はビーズ像を接しない程度で囲まなければならない. しかしながらマイクロディスク法で は内部にROIの設定が可能であるためビーズ法よりも高いレスポンスのCT值が得られる.

Fig. 4 SSP. 測定にマイクロディスク法とビーズ法を用いた場合の一例 detector pitch 3.0

(a) micro disk method, (b) bead method

Fig. 5 ビーズ法とマイクロディスク法により得られたMTF

実線はマイクロディスク法, 破線はビーズ法. MTFはSSPをフーリエ変換して得て抢り, 両手法は有意差を認める.

(a) detector pitch3.0, (b) detector pitch6.0

Fig. 6 マイクロディスクが傾いた場合のMTF

実線は 0 度, 破線は2.5度を示し, 異なる角度で測定されたMTFはお㧍むね重なっている。

(a) detector pitch3.0, (b) detector pitch6.0

Fig. 7 ROIの大きさの違いによるMTF(マイクロディスクを2.5度傾けた場合)。実線はROI：約25pixels. 破線はROI：約400pixels. 異なるROIで測定されたMTFはおおおむね重なっている.

(a) detector pitch3.0, (b) detector pitch6.0

Fig. 8 マイクロデイスク法によるノンスパイラルスキャンのSSP (slice collimation $4 \times 1.0 \mathrm{~mm})$. ガントリ一回転あたりのディスク の移動距離は $100 \mu \mathrm{m}$.

Fig. 9 シミュレーションによる入力矩形波のMTF比較

MTFは入力矩形波の幅とCTの再構成間隔に依存する.

Table 